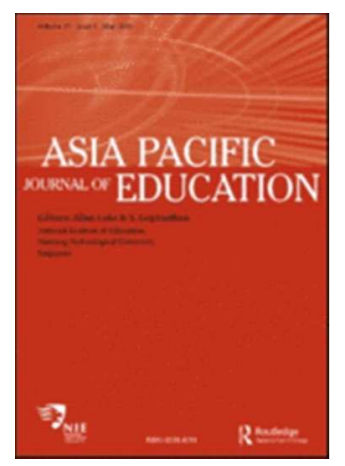

\title{
Tensions and Complexities in School-University Collaboration
}

\begin{tabular}{|r|l|}
\hline Journal: & Asia Pacific Journal of Education \\
\hline Manuscript ID: & CAPE-2012-0258.R2 \\
\hline Manuscript Type: & Original Article \\
\hline Keywords: & \\
\hline \multicolumn{3}{c}{} \\
\\
\multicolumn{3}{c}{$\begin{array}{r}\text { SCHOLARONE } \\
\text { Manuscripts } \\
\end{array}$}
\end{tabular}




\title{
Tensions and Complexities in School-University Collaboration
}

\begin{abstract}
This study, conducted over a one-year period, examined the collaboration practices in a large-scale school-university capacity-building collaborative action research project that was designed to help English language teachers develop the skills needed to deal with the reforms to assessment practices in Hong Kong's school curriculum. The study theorised collaboration as a complex construction that must be understood in the context of the prevailing ideologies shaping professional development practices for teachers. Online data generated from the collaborative action research project were analysed to explore the discursive construction of interpersonal relationships. Critical discourse analysis was used to examine the discursive strategies that were used in the emails of two university researchers and two school teachers to negotiate and manage collaboration practices. It examined the complexities of negotiating collaboration as a social practice in institutional cultures in a non-Western sociocultural setting. The implications of the findings for policy, professional development and future research are discussed.
\end{abstract}

Keywords: school-university collaboration; collaborative action research; teacher professional development; discursive construction; online communication

\section{Introduction}

Since 1997, Hong Kong's educational system has been undergoing major reforms. Professional development policy makers have focused on collaboration between tertiary institutions and schools as a way of improving teaching and learning. Unlike in Western countries, collaborative action research (CAR) projects between schools and universities that focus on the professional development of teachers are not common in Hong Kong. In fact, the notion of collaboration has only permeated education reform policy 
discourse in the last 10 years. The Advisory Committee on Teacher Education and Qualifications (ACTEQ) is the body that regulates the professional development of teachers in Hong Kong. According to ACTEQ, collaboration is the 'way forward' that will make professional development more 'relevant' and school-based and will end 'teacher isolation' (ACTEQ, 2003). In this discourse, collaboration with students, colleagues and the community is presented as a necessary part of professional development. The assumption is that teachers can perform all of these roles without problems, even though collaborative professional development greatly increases their workload.

In the policy documents outlining professional development for Hong Kong teachers, school-university collaboration is presented as achievable and unproblematic. Teacher education institutions are encouraged by the government to collaborate with schools; for example, collaboration between schools and universities is strongly encouraged in research proposals for government-funded projects. However, in reality, school-university collaboration as a professional development practice is frequently characterised by tensions and complexities, and the amount and type of personal and professional investment may vary between the partners (Johnston, 2009; Stewart, 2006; Tsui, Edwards, \& Lopez-Real, 2009).

\section{Tropes of Collaboration in Teacher Education Discourse}

Drawing on Foucault's $(1978,1991)$ theory of genealogy, in this study collaboration is traced as a social practice. Collaboration has frequently been taken to mean democratic cooperation; this understanding hides the problematic power relations that cooperation entails. The notion of building 
relations with another is central to collaboration, and the word collaboration is often used to imply cooperation, mutual reciprocity and equity. CAR in the context of this study refers to school teachers and university researchers who jointly engage in teacher/researcher action research projects within educational organisations as a 'way to involve teachers in wide-scale institutional curriculum change and continuing professional renewal' (Burns, 2009, p. 293). Collaborative research is potentially beneficial, leading to pleasurable and mutually empowering partnerships in which resources and knowledge are shared (Somekh, 1994). However, collaboration has meant different things in different socio-historical contexts, and the term has not always had a positive connotation.

Researchers who have studied collaboration have used different interpretations of the term. Hargreaves (1994) argued that the terms collaboration and collegiality imply two different types of practices, but the terms are used interchangeably in teacher education discourse to cover a broad spectrum of activities ranging from team teaching and co-planning to mentoring and CAR. Hargreaves (1994) defined 'true' collaboration as a sustainable partnership based on mutuality in which the power relations between the collaborators are equal. He compared 'true' collaboration with contrived collegiality, which he defined as a form of implemented partnership that is managed by principals and school managers (Hargreaves, 1994, 2003). In contrast, Burns (1999), Elliot (1991) and Carr and Kemmis (1986) saw collaborative research as a systematic and reflective practice. The latter understanding is rare in Hong Kong, where school-university collaboration is more likely to be perceived by teachers and researchers as a practical 
exchange of resources, rather than as an opportunity for critical reflection and self-empowerment. Tinker-Sachs (2002) identified several key constraints on school-university CAR projects in Hong Kong including a school curriculum that is not conducive to innovative teaching, differing expectations among researchers and teachers and inadequate support from university researchers. Other studies of collaboration (Burns, 1999; Johnston, 2009; Somekh, 1994; Tinker-Sachs, 2002) have suggested that the status and power differentials between teachers and university researchers may be the main factor affecting the social relations in collaborations. However, these studies overlooked some of the broader ideological and political factors that shape collaboration practices at the institutional and societal levels. How power is mediated and constituted in school-university collaboration is an area that merits further research.

\section{Exploring Power in CAR}

This study used Foucault's (1991) ideas of how power and knowledge are constructed and distributed in collaborations to examine how schooluniversity collaboration is negotiated and legitimised. Foucault saw discourses as structured by relations of power (Foucault, 1972, 1991; Rabinow, 1984). Building on the premise that power relations are part of all institutional collaborations, this study examined the discursive construction of interpersonal relations in the online communications of the university facilitators and the teachers in a CAR project. The study addressed the issue of interpersonal relations at the micro-level of collaborative discourse. In particular, it examined how teachers and facilitators negotiate and manage power relations while engaged in collaborative professional development. Foucault (1978) argued that 
power is not simply a set of relations between oppressors and oppressed; power is part of everything, including the micro and macro politics of everyday life (Fraser, 1989; Olssen, 1999). Foucault conceptualised power as a chain or a net in which 'individuals are the vehicles of power, not its points of application' (1978, p. 98). Another conceptualisation is that individuals should not be perceived as simply recipients of power, but as places where power is enacted and resisted (Faubion, 1994; Foucault, 1978; Mills, 2003; Olssen, 1999). Following Foucault's assertion that power circulates everywhere and operates at regional and institutional levels, I examined the email communications between teachers and university facilitators to explore the ways in which 'collaboration' unfolded as an educational practice in a CAR project in Hong Kong. Foucault's ideas allow researchers to problematise the reasoning behind current educational practice. This study examined the asymmetrical power relations between teachers and researchers as expressed in discourse events and in the way in which texts are produced, distributed and consumed in a particular sociocultural context (Fairclough, 2003). Although this study recognised the fundamental role of language and discourse in explaining social life, a more dialectical approach to understanding the structure/agency dichotomy in school-university collaboration was adopted; the study examined how discourse shapes practice and how individual actions shape discourse in a contemporary educational setting (Giddens, 1984).

In the past 15 years, email has emerged as a widely used communication tool for sharing information and transmitting knowledge. Previous research has focused on examining how online communication affects team processes, such as how virtual teams interact and build relationships with 
each other online (Mackenzie, 2000; Martins, Gilson, \& Maynard, 2004; Yates, Orlikowski, \& Okamura, 1999). Martins et al. (2004) argued that email is particularly useful for examining interpersonal processes such as conflict, uninhibited behaviour, the informality of communication among group members, interpersonal trust and group cohesion. The analysis of emails in this study revealed how social relations in collaborative practices are mediated through language.

\section{Research Methodology}

\section{Research Context and Participants}

The research context was a large-scale publicly funded CAR project initiated and organised by a team of English language teacher-educators from a university. The aim of that research project was to help secondary school English language teachers build the skills needed to implement the assessment practice reforms in Hong Kong. Schools were invited to join in the project and participation was voluntary. In the CAR project, university teacher educators acted as facilitators, helping teachers to implement small-scale school-based action research. I was one of the facilitators. I worked with another colleague (Anna) and we 'collaborated' with two teachers (Jennifer and Carol) from Green Hill Secondary School. The teachers chose their own research focus, interventions and data collection methods. The teacher educators provided regular online support to help the teachers implement two cycles of action research over a six month period. There were also three face-to-face meetings. Email was the preferred mode of communication, as the teachers were busy. The support provided by the teacher educators included helping the teachers to 
identify their research focus, co-planning the action research and assisting in the data collection process.

As a teacher educator who is often called upon to engage in different types of collaborative projects with schools, I wanted to conduct a systematic and reflective study of my own 'collaboration' with the teachers and my colleague. At the onset of the CAR project, I invited the two teachers and my co-facilitator to participate in my case study. Ethical clearance for the research was granted by the university. Permission and ethical consent letters were sent to the teachers (Anna and Carol) and my colleague (Anna). Each participant has been given a pseudonym to protect their identities. I was able to observe the collaborative practices between the facilitators and the teachers in the entirety of the two action research cycles. This allowed me to examine how power and social relations can affect school-university collaborations.

\section{Data Collection}

All of the emails between the teacher educators and the two teachers were logged and recorded by the author to create the dataset for this case study. The emails were analysed as a form of spoken discourse. Extracts from 17 group emails were analysed. To verify the interpretation of the email data, follow-up interviews were conducted with the teachers and my co-facilitator (Merriam, 1998). Emails were exchanged between the teachers and teacher educators. All of the emails were group messages written by one person and sent to all members of the sub-group.

A limitation of this research is the dual roles I played in the case study. My position as a researcher and participant in the case study may have 
influenced the way I interpreted the data. Furthermore, my role as a member of the university team may have influenced how the teachers and my colleagues responded to my questions in the follow-up interviews. It is important in qualitative research for the researcher to reflect on and acknowledge how his/her position can influence the findings (Merriam, 1998). To address this issue, I sent a summary of the key findings to the teachers and my colleague and asked them to verify the analysis and my interpretation of the data. This process of member checking addressed the issue of reliability in the analysis of the data and the trustworthiness of the findings. I also acknowledge that in conducting qualitative research, I am representing and reproducing knowledge at the same time (Phillips \& Jørgensen, 2002), thus all of the data are forms of social construction.

\section{Data Analysis}

I drew on social theory and critical discourse analysis (Fairclough, 2003; Foucault, 1991) to analyse how the school and university teachers managed and negotiated their relationships as members of the CAR project; the data for the analysis were the emails exchanged during the co-planning phase of the action research project. This study built on an earlier discursive analysis of interpersonal relations in online communications among English language student-teachers in the construction of a community of practice (Clarke, (2008; Olsen, 2008).

Fairclough's (2003) three-dimensional critical discourse analysis framework was used to analyse the content of the emails and to tease out key interpersonal relation discourse markers (ways of acting) that would provide fresh insights into the tensions and complexities that occur in inter-institutional 
collaboration. Fairclough (2003) argued that analysing the 'ways of acting' in the text (informing, advising, promising, warning, judgement and so forth) is a way to understand how social relations are negotiated and managed. He (2003, p. 105) suggested that to understand the "actional meanings" or ways of acting in a text we must analyse the types of exchange (knowledge exchange, activity exchange), the speech functions (statements, questions, demands, offers) and the grammatical mood (declaratives, interrogative, imperative) in the text. According to Fairclough, we can use the following questions to analyse interpersonal relations. These questions chart the representations of the social actors (the teachers and facilitators) in the text being analysed (2003, p. 145):

- Who is foregrounded, suppressed or backgrounded in the texts?

- Is the social actor realised as a pronoun (I, he, we, you, etc.) or as a noun?

- Is the social actor realised as a participant in the clause or as a possessive noun or pronoun?

- Is the social actor the actor in processes (he/she does things/makes things happen), or the object/beneficiary of processes?

- Is the social actor represented personally or impersonally?

- Are names used? Is the social actor referred to as an individual or as a member of a group?

- How are the social actors classified in the text? (Are teachers a generic group?)

My analysis of the discursive strategies used by the teachers and the facilitators to represent their actions, examined collaboration through a critical lens and shed light on the challenges of negotiating interpersonal relations at three levels and in three contexts: the personal, the institutional and the sociocultural. For example, I identified the ways in which requests were made, how advice was given and how teachers and facilitators managed agreements and disagreements. 
Figure 1. Fairclough's Three-Dimensional Framework for Critical Discourse Analysis.

$<$ Insert figure 1>

Drawing on Fairclough's framework, the emails were analysed in two parts. First, the recurring discursive features in the emails were analysed; these features included word choice, textual features and expressions used by the writers. The texts were then examined in context to determine how particular textual features and choices of words and expressions were used by the writers to negotiate interpersonal relations. The assumption was that email discourse is a social practice, and thus reflects the social relations of group members. The analysis of email texts can thus reveal how representations of reality were produced through language by the teachers and researchers while they were collaborating online. In addition to the critical discourse analysis framework, Martin and Rose's (2003) discourse analysis theory was used to analyse the positional and relational sources of the attitudinal statements in the emails. Attitudinal vocabulary can be both positive and negative. Martin and Rose (2003) proposed that analysing how attitudes (attitudinal vocabulary and phrases) are negotiated can reveal the intensity of the 'feelings involved and the ways in which values are sourced and readers aligned' in the text (Martin \& Rose, 2003, p. 22). Analysing appraisals in a CAR project discourse can be an effective way to problematise interpersonal relations in a situated context, because appraisals reflect more than just a person's personal opinion, judgment or appreciation; they also reflect institutional positioning within the wider social context (Martin \& Rose, 2003). 
The emails were first coded to identify the key themes. This step identified the categories and frequencies of strategies used by the facilitators and teachers to negotiate and manage interpersonal relationships during the collaboration process (Cohen, Manion, \& Morrison, 2007). The prominent linguistic features in the emails, including word choice, metaphors and pronouns, were then analysed. The links between discursive practices and broader social and cultural developments and structures' (Phillips \& Jørgensen, 2002, $p$ 78) in the texts were explored to show how collaborative discourse draws on discourses and texts beyond the project context, such as the reform discourse, corporate discourse, institutional discourse and professional development discourse. How 'collaboration' was construed by the teachers and researchers in the emails was examined to determine whether the same linguistic features (e.g. how requests were made and how appraisals were given) were used to negotiate changes in the action research plan across a series of texts, or combined to form new articulations (Fairclough, 2003; Phillips \& Jørgensen, 2002). The following discursive strategies were the most common in the emails:

- giving appraisals;

- giving thanks;

- giving feedback;

- negotiating change;

- giving suggestions. 


\section{Negotiating Interpersonal Relations in the CAR Project}

One area of research in the CAR literature is how to reduce the power and status differentials between school teachers and university researchers. The aim of this analysis was to determine if this goal was achieved in the case study.

In the initial phase of the CAR project, the facilitators exchanged a series of emails with the teachers to co-construct a plan for the action research project. The facilitators and teachers negotiated the areas on which to focus the project. A recurring theme in the emails was the teachers' requests for feedback from the facilitators. Hence, the discourse of feedback and praise featured strongly in the emails written by the facilitators. A typical discursive strategy used by the facilitators in this series of emails was to begin the message with an appraisal of the teachers' action research ideas. Some examples of their appraisals and praise are given below.

- Your plan looks great and I particularly like the idea of the 'feed in stage'. This is so important at this level. (Email 1, facilitators to teachers.)

- I've just had a quick look at your revised plan. It looks good. The change you have made is to allow students to view the video in the second cycle, which is great. (Email 2, facilitators to teachers.)

- Your recommendation to do lots of practice in junior forms is a good one to help students to develop effective interactive skills in English over time. (Email 5, facilitators to teachers.)

- The recommendations look fine - perhaps add also the affective issue of taking the formality out of the interactive task situation as much as possible to ensure that students are at ease and as relaxed as possible so that they can do their best. (Email 5, facilitators to teachers.)

The underlined phrases in the above extracts exemplify the facilitators' wish to establish a good rapport with the teachers and to create a supportive environment for the further negotiation of ideas. The facilitators' feedback 
highlighted what they thought was good in the teachers' plan and why the recommendations were sound. They also expanded on each positive remark to clarify why they thought the teachers were on the right track. In giving feedback to the teachers, the facilitators were acting as 'experts'; they were approving the teachers' ideas for the action research project. According to Martin and Rose (2003), the use of appraisals in everyday discourse exemplifies an unequal social relationship between people. The social relations negotiated in the foregoing extracts illustrate the unequal status between the facilitators and the teachers; because the feedback is unidirectional, the appraisals written by the facilitators exemplify a social relationship between people who know a subject (the experts) and people who do not (the non-experts). In a follow-up interview with the teachers, Carol and Jennifer explained why they perceive the university researchers as 'experts':

Interviewer: What was your motivation for participating in these different collaborative projects?

Jennifer: We want to get different views from universities and the EDB [Education Bureau] because they are professional and they can give us a lot of advice and comments on our learning and teaching here.

The 'unequal' social relationship is also clear in the emails written by the teachers to the facilitators. The emails contained frequent 'thank you statements' from the teachers.

- Thank you very much for your suggestions. (Email 4, teachers to facilitators.)

- Thanks again for your kind help! (Email 4, teachers to facilitators.)

- Thanks for your editing and for analysing the data. (Email 6, teachers to facilitators.)

- Here is the amended version of the research plan. Changes have been made in the first cycle. Please see if there is anything we need to improve. Thanks a lot! (Email 4) 
In these extracts, the teachers thank the facilitators for their suggestions, help and expertise. The phrases used suggest that the teachers were appreciative of the facilitators' support; they also reflect the teachers' doubts about their own ability to carry out action research. In the following comments from the follow-up interviews with the teachers, the teachers explained what types of facilitator support they found useful in the CAR project:

Interviewer: What types of support did you find useful from the university, and from the CAR project facilitators?

Carol: Presenting what we did in a more systematic way. Yes, because we had to write down the schedule; and then you gave us a lot of support, because without the support I think we couldn't have done the tape recording (data collection).

Interviewer: What do you see as the benefits of collaborating with an outsider, an outside partner?

Jennifer: We can get professional ideas from the other groups who give us comments and feedback on how we can improve ourselves. Communication is important because we always need to keep in contact via emails and phones and we get time together to discuss things.

Jennifer used the word 'professional' to describe the input provided by the university. Positioning the facilitators as 'professionals' makes the teachers the 'non-experts' or learners in the context of the collaborative relationship. This relationship was also demonstrated in the following email:

\section{Dear Anna,}

Thank you very much for your suggestions. They'll be useful for us to make changes. We will discuss the plan and make the amendments

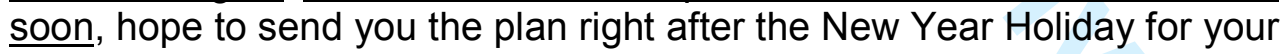
reference.

Thanks again for your kind help!

\section{$\underline{\text { Regards, }}$}

Jennifer Lee

(Email 3, sent by Jennifer to Anna.)

The tone and mood of the teacher's email was formal. Jennifer thanked the facilitators twice, both at the beginning and at the end of the message. The 
teacher stated that she will discuss the plan with her colleague, but in the same sentence indicated that the facilitators' suggestions would be implemented and that the teachers' plan would be amended ('We will discuss the plan and make the amendments'). The email presented the facilitators as the experts who can legitimately evaluate the action research plan. There were no examples in the teachers' emails of appraisal or detailed feedback, which were a notable feature of the facilitators' emails. This analysis of the appraisal and feedback discourse in the project emails indicated that the facilitators and teachers did not share equal status and roles, as only the facilitators had the authority to give feedback. In this way, the facilitators were constructed as experts in the emails, and both the teachers' and facilitators' institutional identities were reinforced. This analysis demonstrated the status and power differential between the teachers and university researchers working together in this CAR project.

Two other common discursive strategies used in the emails by the facilitators to negotiate change was the use of modals and tentative language.

- I am wondering if you might consider making a very explicit change in cycle 2 and this could be to negotiate or discuss criteria for successful task input completion, based on the input your students receive in the feed-in stage in cycle 1 so making the criteria very explicit. What do you think? Does this seem too radical a change? (Email 1, facilitators to teachers.)

- Could you have a look and see if you think this is better or worse than the original!! (Email 2, facilitators to teachers.)

- I have made a few changes to the abstract to make the findings more tentative and to focus on self-assessment and participation in feedback events, is this OK? (Email 7, facilitators to teachers.)

- Could you have a look at them and see what you think? If you feel that these points reflect your own views then please feel free to use all or some and present them as your own findings and recommendations in your presentation. (Email 8, facilitators to teachers.)

In the group emails, it was predominantly the facilitators who gave advice and suggestions, but they always used tentative language. Modals were frequently 
used by the facilitators as a discursive strategy to express the possibility of an alternative action. In the follow-up interview with Anna, she explained why she used tentative language in the emails to the teachers:

Interviewer: What types of support have you provided for the teachers since the launch of the project?

Anna: I gave the teachers lots of information on feedback, examples of research plans, surveys and all sorts of materials. We did a few tasks (in the workshops), even some data analysis, even though they might not have to go into that. Before the interview, there were several emails going back and forwards. They sent their research plans and I made comments, quite tentative about it because you know I am not used to doing this sort of thing. I don't want to force people to do things they don't want to do! I would send them the email and you would follow up with a phone call. I think those phone calls, that personal input has really helped make all of the groups really gel with us, the relationship between the university and the school and the research team in each school, I think the phone calls really made a difference... It's not a question of you and us, but a question of we are co-investigating this together!

(Interview, 28 March 2007)

The facilitators used tentative language because they did not want to impose their ideas on the teachers. The questions in the emails offered teachers a choice and invited them to demonstrate their expertise (e.g. 'Could you have a look at them and see what you think?'). The facilitators also adopted another discursive strategy to downplay their position as research experts - they explicitly invited the teachers to ignore any suggestions that they did not find useful.

- Please ignore what is obvious, and use any ideas that might be helpful. (Email 3, facilitators to teachers.)

- Use whatever you want to - or nothing at all from our meeting notes! (Email 3) 
The discursive strategies used by the facilitators in these emails suggest that there was an attempt to create equity in the decision-making process. In the follow-up interview, Anna explained why the facilitators tried to respond to the teachers at an 'equal' level:

Interviewer: How do you think your style differs from other group leaders?

Anna: The difference is perhaps I am a lot more tentative and a lot less experienced in doing this sort of thing. So I am learning as everybody else is learning, but I think about how to do action research and what it means to be in the process...I feel I am at the stage that they're at, but doing slightly different things; but I can respond to the teachers at a much more equal level, not just someone from the university, but someone trying to find out about something, so perhaps that helps other people (teachers) to relax. Also, I also feel insecure about it, so I want to give the support to other people so they don't feel that way.

(Interview, 28 March 2007)

The follow-up interview with Anna suggests that the facilitators wanted to downplay their institutional identity and their authority as teaching and research experts and to establish a more 'equal' interpersonal relationship with the teachers. However, the choice of discursive strategies used in the emails reflects, to some degree, the tensions in the power relations between the facilitators and the teachers in the collaboration process. The facilitators resisted claiming the role of expert, but the following excerpts show that they offered a lot of advice to the teachers.

- l've made some notes of our discussions and have attached them above. I'm also attaching parts of a session I did with some teachers on Teaching Speaking with ideas (towards the end of the notes) about integrating speaking and peer assessment with normal grammar type 
lessons as a natural part of the learning cycle. (Email 3, facilitators to teachers.)

- Many thanks for this. I'm still looking through the data and will be able to make more recommendations. l'll try and write it all up tomorrow and then send it to you. (Email 6, facilitators to teachers.)

- I am attaching some thoughts with regard to findings and recommendations based on a more in depth analysis of your video clips and the transcriptions. I have tried to make the recommendations from your perspective based on your comments in Forum 4. (Email 8, facilitators to teachers.)

The facilitators used modals and questions in their emails to emphasise the equality in the power relations between themselves and the teachers. Suggestions were always presented to the teachers as ideas to consider rather than as instructions for change. However, the teachers did not seem to acknowledge the attempted democratic social relations constructed by the facilitators, and accepted most of the suggestions made by the facilitators without question. Furthermore, when the teachers needed advice on presenting the data at an action research conference, they asked for it directly.

- When I read the format of the presentation, the steps may be different from the Power Point slide that l've prepared before. Is it OK or do I need to change the steps? (Email 5, teachers to facilitators.)

- How can the video clips match the findings e.g. feedback should not be given in Cantonese? And how can we show the findings from the questionnaire in the slide? In a bar chart? pie chart...etc.? (Email 5, teachers to facilitators.)

Discursive strategies to establish equity and shared-ownership of the project did not feature in the emails written by the teachers. For example, the analysis of the choice of pronouns in the emails showed that the pronouns ' $y o u$ ' and 'your' were the most frequently used pronouns in the emails written by both facilitators and teachers. Pronouns are used in texts to include and exclude members of a group. In the following email extracts written by the facilitators, the pronouns highlight the teachers' ownership of the action research project.

- Your plan looks great. 
- Could you have a look at them and see what you think? If you feel that these points reflect your own views then please feel free to use all or some and present them as your own findings and recommendations in your presentation. (Email 8, facilitators to teachers.)

- I've put this on your revised plan. Could you have a look and see if you think this is better or worse than the original!

The facilitators' choice of pronouns suggests that they were acknowledging that the teachers were the owners of the action research. However, this acknowledgement that the action research belonged to the school also made the teachers responsible for the results.

In general, the emails written by the teachers did not feature the same discursive strategies, such as modals or tentative language, as the emails written by the facilitators. The emails written by the teachers construed the facilitators as 'experts'. One explanation for this difference was that the teachers did not share the same understanding of collaborative professional development as the university educators. In this follow-up interview, Jennifer explained what she expected to gain from participating in the project:

Interviewer: What do you see as the learning outcomes for teachers? For the school? For yourself?

Jennifer: I think for the school we have learnt a lot from the outside parties; what they have done and from the projects. For myself...personal growth. Participating in the project and discussing things with other colleagues, sharing the ideas and discussing them with the university staff. Also the help from the technicians and other support, this has given me lots of personal growth.

The emails were a vehicle for the facilitators and teachers to negotiate their respective roles and relationships with each other as 'collaborators'. This analysis of the discursive strategies used in the online communications by the teachers and facilitators reflects the uncertainty and ambiguity in the construction of the relational positions and identities in this CAR project. 


\section{Discussion and Concluding Remarks}

The above analysis demonstrated that negotiating interpersonal relationships in the context of a CAR is highly complex. In tracing how the two facilitators and two teachers managed and negotiated their social relationships, we showed that in this case study establishing shared ownership was a more ambiguous and opaque process than in the examples presented in the CAR literature (Burns, 1999; Elliott, 1991; Oja, 2001; Stenhouse, 1975). The findings indicated that shared power and equity were not achieved in this project. The facilitators persistently managed power relations by downplaying their institutional identities in an attempt to construct a 'harmonious' and 'collaborative' relationship. At the same time, there were contradictions and tensions in the texts, because the teachers did not acknowledge the democratic set-up constructed by the university educators. In the emails, they resisted presenting themselves as having equal status. The 'collaboration' practice constructed in these emails, at best reflected inter-institutional 'cooperation'. The discursive strategies used in the emails reflected a 'co-operative' trainertrainee social relationship between facilitators and teachers. These texts reflected the traditional understanding of school-university collaboration that positions university facilitators as knowledge providers, and teachers as participants. The social relationships constructed in this CAR study were hierarchical in the sense that the teachers expected the facilitators to 'authorrise' their ideas for the action research project. However, in the emails, this hierarchical relationship was obscured by strategies of politeness used to maintain the appearance of equality. The emails also revealed differences in how the facilitators and teachers viewed collaboration. For example, the 
facilitators used discursive strategies that minimised imposition and promoted solidarity, but the teachers did not appear to acknowledge the democratic setup constructed by the facilitators, thus illustrating how power relations were present, but were constantly managed through the use of politeness.

The current CAR literature problematically emphasises the development of a single vision for practice, and ignores the complexities of institutional culture and politics that characterise particular sociopolitical contexts. This criticism of institutional 'collaboration' as a practice in professional development has been highlighted in other studies of collaboration (Hargreaves, 1994; Lefever-Davis, Johnson, \& Pearman, 2007; Siskin, 1994; Stewart, 2006). Collaboration as a goal for professional development has often been presented as a democratic practice that will build collaborative cultures in institutions, including schools and universities. However, reforms that aim to 'foster' schooluniversity 'collaboration' may conceal the extent to which power operates; Foucault $(1985,1990)$ described this hidden power, as 'capillary power' and argued that it regulates professional practices through institutional bodies. The discourse of collaboration foregrounds democracy and accountability, but at the same time it subjugates teachers to a wide range of additional professional development practices that add to their workload. The online communication in this study showed that in this case, the teachers and facilitators did not adhere to the 'democratic' goals promoted in CAR literature, but rather negotiated their own understanding of collaboration, which reflected their institutional agendas. In practice, achieving equality is complicated by the competing discourses that shape practice. Our findings showed that the facilitators were not able to 'neutralise' the hierarchical power relations in the partnership. It is not surprising 
that the teachers construed the facilitators as experts. The teachers and facilitators co-constructed a collaboration practice that reflected their individual institutional and societal practices. In the sociocultural context of Hong Kong, most school-university collaborative projects are still initiated by university researchers, and teachers still predominantly play the role of participants. Even if, as in this study, university researchers position themselves as co-learners, this does not necessarily neutralise the hierarchical power relations in the partnership, as institutions are intrinsically bound up with power and are connected to the interests of particular groups in society. For example, in this study the university legitimised its power by presenting its researchers as assessment consultants and action research facilitators who were authorised to exercise their expertise in the context of the CAR project. The emails cast the two facilitators as experts who were invested with institutional authority; the non-experts (the two teachers) accommodated themselves to these institutional norms.

The collaboration practices enacted in this case study were also regulated by other social practices operating at the time of the CAR project, including the dominant professional development and reform discourses. For example, the teachers stressed their role as learners rather than as coresearchers, because implementing assessment practices was new to them and they perceived the CAR project as an opportunity to learn more about giving feedback to students. The teachers did not acknowledge the tropes of shared ownership and equity that have become prominent in the schooluniversity collaboration literature. Instead, they negotiated and revised the rules for collaboration to suit their own professional needs. In this way, the project 
became the 'site of struggle over meaning and identity' (Talbot, Atkinson, \& Atkinson, 2003, p. 74), as the teachers and facilitators negotiated and renegotiated collaboration as a system of beliefs, interpersonal relations and identities. These findings indicated that collaboration is not a fixed relationship, but is an on-going process of negotiation. The teachers and researchers collaborated in an inter-institutional context and used language to construct a social reality through the enactment of beliefs, power relations and identities. The findings of this research suggest that collaboration between schools and university cannot be constructed outside and beyond relations of power, even when the participants claim to have established a discourse of mutual partnership.

One implication of the findings is the need for researchers to improve the power imbalance in school-university collaborative projects. Currently, CAR projects are predominantly initiated by university-teams, and teachers are then invited to be participants, usually to help the researchers with data collection. This limits teachers' power to negotiate research goals and professional growth. The findings also indicate that the more sustainable, reflective and critical collaboration practices identified in the teacher education literature as being useful for professional growth were not achieved in this CAR project (Carr \& Kemmis, 1986; Day \& Sachs, 2004). Teachers need to be provided with easier access to resources that would allow them to initiate school-based action research for professional development. Policy makers and principals also need to resist presenting school-university collaboration as a panacea for educational problems in schools. 
To conclude, collaboration is socially constructed through discourse. This critical examination of school-university collaboration challenges the discourse in the professional development literature that advocates this practice as good and necessary for teachers. At the moment, collaboration practices are not sufficiently problematised in the context of teacher education and other fields. The findings of my study show the potentially negative consequences of advocating collaboration practices that can lead to confusion and a superficial professional development experience for the teacher. CAR is advocated across disciplines as a useful practice for learning and development. This study suggests that practitioners should critically evaluate collaboration as a social practice to address the issues of power and control. In this study, emails were critically examined to identify the construction of power relations in a CAR project. In future projects, teacher educators should reflect on their own practice and consider how interpersonal relations with school teachers are negotiated and managed. Exploring how power works in inter-institutional practices, including online communications, would be a useful direction for further research.

\section{References}

ACTEQ. (2003). Towards a Learning Profession. Hong Kong: HKSAR Government Publication.

Burns, A. (1999). Collaborative Action Research for English Language Teachers. Cambridge: Cambridge University Press.

Burns, A. (2009). Action Research in Second Language Teacher Education. In A. Burns \& J. C. Richards (Eds.), The Cambridge Guide to Second Language Teacher Education. New York: Cambridge University Press.

Carr, W., \& Kemmis, S. (1986). Becoming Critical. Victoria: Deakin University Press. Clarke, M. (2008). Language Teacher Identities. Clevedon: Multilingual Matters.

Cohen, L., Manion, L., \& Morrison, K. (2007). Research Methods in Education (6th ed.). Abingdon: Routledge. 
Day, C., \& Sachs, J. (2004). Professionalism, Performativity and Empowerment: Discourses in the Politics and Purposes of Continuing Professional Development. In C. Day \& J. Sachs (Eds.), International Handbook on the Continuing Professional Development of Teachers. Maidenhead: Open University Press.

Elliott, J. (1991). Action Research for Educational Change. Milton Keynes: Open University Press.

Fairclough, N. (2003). Analysing Discourse. Abingdon: Routledge.

Faubion, J. D. (1994). Michel Foucault. London: Penguin Group.

Foucault, M. (1972). The Archaeology of Knowledge (S. Smith, Trans.). London: Tavistock.

Foucault, M. (1978). The Will to Knowledge. London: Penguin.

Foucault, M. (1985). The History of Sexuality Vol. 2. New York: Vintage Books.

Foucault, M. (1990). The History of Sexuality (R. Hurley, Trans. Vol. 1). New York: Vintage Books

Foucault, M. (1991). Discipline and Punish: The Birth of the Prison (A. Sheridan, Trans.). London: Penguin.

Fraser, N. (1989). Unruly Practices: Power, Discourse, and Gender in Contemporary Social Theory Minneapolis: University of Minnesota Press.

Giddens, A. (1984). The Constitution of Society Cambridge: Polity Press.

Hargreaves, A. (1994). Changing Teachers, Changing Times. London: Continuum.

Hargreaves, A. (2003). Teaching in the Knowledge Society: Education in the Age of Insecurity. Maidenhead: Open University Press.

Johnston, B. (2009). Collaborative Teacher Development. In A. Burns \& J. C. Richards (Eds.), The Cambridge Guide to Second Language Teacher Education. New York: Cambridge University Press

Lefever-Davis, S., Johnson, C., \& Pearman, C. (2007). Two Sides of Partnership: Egalitarian and Enpowerment in School-University Partnerships. Journal of Educational Research, 100(4), 204-210.

Mackenzie, M. (2000). The Personal Organization of Electronic Mail Messages in a Business Environment: An Exploratory Study. Library and Information Scinece Research, 22(4), 405-426.

Martin, J. R., \& Rose, D. (2003). Working with Discourse: Meaning Beyond the Clause. London: Continuum.

Martins, L., Gilson, L., \& Maynard, M. (2004). Virtual Teams: What Do We Know and Where Do We Go From Here? Journal of Management, 30(6), 805-835.

Merriam, S. B. (1998). Qualitative Research and Case Study Applications in Education. San Francisco: Jossey Bass.

Mills, S. (2003). Michel Foucault. London: Routledge.

Oja, S. N. (2001). Confronting the Good, the Bad, and the Moral through Collaborative Action Research. American Educational Research Association.

Olsen, B. (2008). Teacher Education Quarterly Summer, 35(3), 1-4.

Olssen, M. (1999). Michel Foucault: Materialism and Education Westport: Bergin and Garvey.

Phillips, L., \& Jørgensen, M. (2002). Discourse Analysis as Theory and Method. London: Sage Publications.

Rabinow, P. (Ed.). (1984). The Foucault Reader. London: Penguin

Siskin, L. S. (1994). Realms of Knowledge: Academic Departments in Secondary Schools. Abingdon: Routledge Falmer. 
Somekh, B. (1994). Inhabiting Each Other's Castles: Towards Knowledge and Mutual Growth through Collaboration. Educational Action Research, 2(3), 357-381.

Stenhouse, L. (1975). An Introduction to Curriculum Research and Development. London: Heineman Educational Books.

Stewart, T. (2006). Teacher-Researcher Collaboration or Teachers' Research. TESOL Quarterly, 40, 421-430.

Talbot, M., Atkinson, K., \& Atkinson, D. (2003). Language and Power in the Modern World. Edinburgh: Edinburgh University Press.

Tinker-Sachs, G. (Ed.). (2002). Action Research in English Language Teaching. Hong Kong: City University Press.

Tsui, B. M. A., Edwards, G., \& Lopez-Real, F. (Eds.). (2009). Learning in SchoolUniversity Partnership: Sociocultural Perspectives. London: Routledge.

Yates, J., Orlikowski, W., \& Okamura, K. (1999). Explicit and Implicit Structuring of Genres in Electronic Communications: Reinforcement and Change of Social Interaction. Organization Science, 10(1), 83-103. 


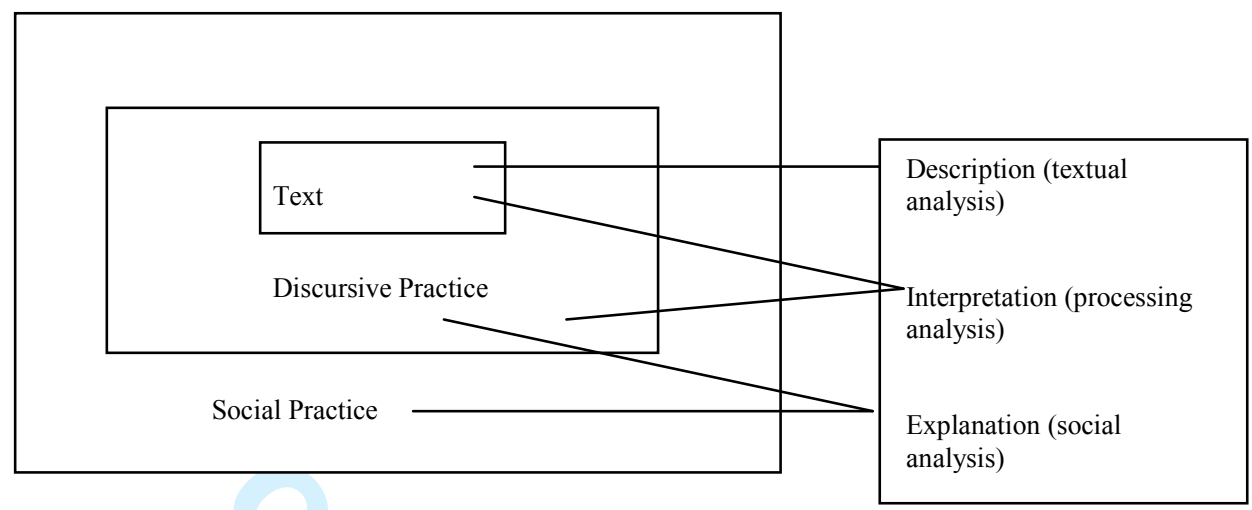

